such a tumultuous sensation before,' said the Professor, 'as when all alone in the still room I heard the needles click; and as I spelled the words, I felt all the magnitude of the invention, now proved to be practical beyond cavil or dispute.' The telegraph thenceforward, as far as its mechanism was concerned, went on without a check, and the modifications of the instrument, which is still in use, have been made for the purpose of rendering it more economical in its construction and working, two wires at present being employed, and in some cases only one."

\section{Artificial Digestion}

The British and Foreign Medical Review of July 1837 contains the following information: "Dr. T. J. Todd of Brighton with the assistance of $\mathrm{Mr}$. Schweitzer of the German Spa, Brighton, has been performing experiments with the artificial digestive fluid, in imitation of those of Schwann in Berlin and has arrived at some new and interesting results not attained by Dr. Schwann. The digestive fluids with which Dr. Todd operated were prepared from the stomachs of the ox, the horse, the dog and the cat. Some, also, prepared from the upper portion of the small intestines, was found not less powerful. The presence of the acid is essentially necessary in the preparation; when Mr. Schweitzer endeavoured to procure the digestive fluid with distilled water alone, or when he treated the mucous membrane in the same way with a weak alkaline solution, a rapid putridity stopped all further proceedings. Various animal and vegetable substances were submitted to the action of these digestive fluids, at the ordinary temperature of the atmosphere, and the contact result in all the instances had been that these substances have been resolved into their elementary organic globules.'

"There has been no exception to this, so far as the experiments have extended, and these include among vegetable substances the artificial digestion of boiled cauliflower, of bread, and of vermicelli, not dressed; and among animal substances, the white of egg boiled, the coagulation of blood, butter, fat, the muscular fibre of mutton and of fish boiled and raw, filaments of the sciatic nerves raw, and scrapings of bone. The products of these artificial digestions especially of the vegetable substances compared with chyme taken from a dog which had been feeding upon ground oats, were very much alike, except that the watery part had been removed from the chyme."

\section{Cure for Drunkenness}

The issue of the Indian Journal of Medical and Physical Science of July 1837 contains the following information: "A native of Norway, aged 40, who had from his youth been accustomed to dram drinking, was attacked with delirium tremens. His medical attendant to cure him of his dangerous propensity, prescribed the daily dose of a mixture of two drachms of sulphuric acid and twenty-four ounces of whisky. The result was remarkable. In three months' time he got such a dislike to all kinds of spirituous liquors that he could not bear to swallow a drop of anything stronger than beer. The dose of the above mixture taken, was four wine-glasses daily, and the cure had been of a year's standing at the time of the communication of the case."

\section{Societies and Academies \\ Dublin \\ Royal Irish Academy, May 10.}

W. J. McCALLIEN : Structure of the Rathmullen District, Co. Donegal. An account is given of the Crana quartzite in the district between Rathmullen and Milford. It can be split into three divisions. The structure of the quartzite group is described, and emphasis is laid on the value of the epidiorite sills in the interpretation of the structure. The base of the quartzite is believed to be a slide, which is folded and overfolded. The Killygarvan limestone, which is younger than the Crana quartzite, is correlated with the Culdaff limestone.

\section{Cape Town}

Royal Society of South Africa, April 21.

Archæology of the Oakhurst Shelter, George. (1) A. J. H. Goodwin : Course of the excavation. A description of general methods of excavation, stratigraphy, and cultural remains as observed on six visits to the Oakhurst Shelter. (2) Disposition of skeletal material. An account of the graves, their cultural age and associations, positions of burial and grave furniture. (3) M. R. Drennan: The cavedwellers. An anthropometrical and descriptive account of the adult population of the shelter. (4) Children of the cave-dwellers. An anthropometrical account of the child population of the shelter, stressing growth and development in relation to the adult group. (5) J. F. Schofield : 'The pottery. An account of the pottery found in the superficial deposits at Oakhurst shelter.

P. W. LAIDLER : An unusual grooved stone.

J. F. SCHOFIELD : Pottery from the Umgazana and Zigzag caves.

\section{Cracow}

Polish Academy of Science and Letters, April 5.

Th. Banachiewicz: The inverse of a Cracovian, and a general solution of a system of linear equations.

W. JACYNA : The differences in the indications of gas thermometers. A helium thermometer at constant pressure gives higher readings than a helium thermometer with the gas at constant volume if the temperature is higher than $-100^{\circ} \mathrm{C}$.

F. GorsKI: The polarimetric titration of the oxyacids. The author adds an excess of ammonium molybdate, to increase the rotatory power, and titrates with a standard solution of the optical isomer of opposite sign. Errors due to various secondary factors are thus eliminated.

MME. H. KRZEMIENIEWSKA and S. KRZEMIENIEWSKI : (1) The Myxobacteria-cellulose-degrading agents. Description of Myxobacteria, especially the family Sorangiacer, capable of living on cellulose in the pre sence of free oxygen. These bacteria can be grown on a synthetic medium containing cellulose and nitrates. (2) The degradation of cellulose by the Myxobacteria. J. BADIAN : The cytology of yeasts.

W. Niesrolowski and R. Wojtusiak : The geographical extension of forms of the species Erebia manto, especially in the eastern Carpathians.

J. ZACWILICHOWSKI : Experimental researches on the behaviour of acquired characters in the descend. ants of Lymantria dispar.

B. Hry NIEwIECKI : Count Michel-Jérôme LeszczycSuminski, and his study of the development of ferns. 


\section{Moscow}

Academy of Sciences, (C.R., 14, No. 8 ; 1937.)

V. S. IgxatovskiJ : The Laplacean transforma. tion (5).

P. Konovkrn : A generalization of Taylor's series.

V. Sozolovskis : Concerning a problem of the theory of shells.

N. StreleckiJ : The factor of safety as an indicator of strength equality of structures.

E. P. OstrovskiJ : Generation of powerful sound vibrations by magnetostriction.

K. СH. Kek ̌̈Eev : Action of non-adequate stimuli on receptors.

A. E. FayorskiJ and M. D. Bone : Methods of determination of the constitution of carbohydrates of the series $\mathrm{C}_{n} \mathrm{H}_{2 n-2}$.

P. Schorigin and S. A. SkoblinskaJa : The decomposition of ethers (and esters) of cellulose by a solution of metallic sodium in liquid ammonia.

F. M. SEMTAKIN and A. I. LAzAREva : (1) A study of periodic precipitation in aqueous media in capillaries, in the formation of barium carbonate, copper chromate and silver sulphate. (2) Comparative study of periodical precipitations in aqueous media by the Morse and the Ostwald methods.

L. G. Dobrunov: Characteristics of the growth and mineral nutrition of hemp with simultaneously maturing male and female plants.

N. V. Morosova-VodjanitskaJa : Some data on the vegative productivity of the Black Sea.

\section{Rome \\ National Academy of the Lincei (Atti, 24, 323-392; 1936).}

E. Bompiani : Projective invariants in the theory of surfaces (1). Rapid reconstruction of the theory of projective applicabilities.

L. Tonelli : Problem of Plateau (1).

N. Abramescu : Study of a surface in the region of one of its points, and a new interpretation of the cubic given by the tangents of Darboux and Segre.

E. Castelnuovo: A class of rational surfaces which admit $\infty^{2}$ transformations projective in themselves.

A. Erdélyi : The generalization of a formula of Tricomi.

L. Rотн : Semi-rational varieties in three dimensions.

L. Cesari and F. Conforto: The equation of the three moments for a continuous bent beam stressed axially, with a bending rigidity which is variable linearly along each span (2).

L. LABоcCETtA : A more general form of Kepler's third law.

G. ARrighr: Isocarene oscillations about the configurations of general equilibrium.

R. Manzoni Ansider: Raman spectrum of aromatic hydrocarbons with condensed nuclei (1). Anthracene and phenanthrene, and their molecular symmetry.

G. B. Bonino: Molecular symmetry of thiophene (2).

G. Natta and R. Rigamontr : Electron diffraction examination of some vinyl polymers.

E. TRIA: Relation between temperature and activity of the glycogenolytic ferment in the liver of poikilotherm animals.

\section{Appointments Vacant}

APPLICATIONS are invited for the following appointments, on or before the day mentioned:

Professor of Ctvir Engineering, Irrigation and Hydraulic in the Thomason Civil Engineering College, Roorkee, United Provinces, India-High Commissioner for India, General Department, India House, Aldwych, London, W.C.2 (July 31).

HEAD OF THE DEPARTMENT OF ENGINEERING, ARchitecture AND Bullding of the Bradford Technical College-The Principal (July 31). Assistant EngrnekR in the Mechanical and Vehicle Engineering Section at the Headquarters of the Ministry of Transport-The Establishment Officer (July 31).

Assistant CURAtor in the Rock Garden and Herbaceous Department of the Royal Botanic Gardens, Kew-The Secretary, Ministry of Agriculture and Fisheries, 10 Whitehall Place, London, S.W.1 (August 3).

Promanent Assistant (metallurgy) in the Admiralty Technical Pool-The Secretary of the Admiralty (C.E. Branch) (August 7).

Professor of Forestry in the University of Aberdeen-The Secretary (November 1).

Assistant Lecturer in Civil Enginegring in the Imperial College of Science and Technology (City and Guilds College)-The Secretary.

Thacher of ENGINFERINe in the Oldham Municipal Technical College--The Director of Education, Education Offices, Oldham.

LECTURER IN MATHEMATICS and LECTURER IN CHEMISTRY in the Kingston Technical College-The Principal.

LFoturer IN ENaINeERING in the Brighton Technical CollegeThe Education Officer, Education Offices, 54 Old Steine, Brighton, 1. ABSTRACTOR of scientific and technical literature at the Shirley Institute, Didsbury, Manchester-The Director of Research.

\section{Official Publications Received}

\section{Great Britain and Ireland}

P E P (Political and Economic Planning). Report on the British Social Services: a Survey of the existing Public Social Services in Great Britain with Proposals for Future Development. Pp. 206. (London: P F P.) Paper boards, 78. 6d.; cloth, 108. 6d. [186 London School of Hygiene and Tropical Medicine. Report of a Meeting of the Ross Institute Industrial Advisory Committee held in the Council Chamber of the Rubber Growers' Association on Friday, 28th May 1937. Pp. 24. (London: London School of Hygiene an-
[306

The Story of the General Register Office and its Origins from 1538 to 1937 . Compiled by the Registrar General and illustrated by certain Exhibits shown at the General Register Office, Somerset House, Strand, W. C.2, in commemoration of the Centenary 1837-1937 of the General Register Office and Registration Service in England and Wales. Pp. $30+6$ plates. (London: H.M. Stationery Ofice.) $6 d$. net.

Transactions of the Royal Society of Edinburgh. Vol. 59, Part 1, No, 5: The Early Stages in the Development of the Ferret; the Formation of the Mesoblast and Notochord. By Dr. William J. Son, Ltd.; London: Williams and Norgate, Ltd.) 6s. 3d. [306 Committee on Bird Sanctuaries in Royal Parks (England). Report for $1936^{\circ}, \mathrm{Pp}, 35$, (London: H.M. Stationery Office) 9d. net. [17 Scottish Education Department. Report on the Royal Scottish

Museum, Edinburgh, for the Year 1936. Pp. 19. (Edinburgh and
London: H.M. Stationery Office.) 3d. net.

\section{Other Countries} Imperial College of Tropical Agriculture. The Principal's Report
for the Year 1935-36 and the Accounts for the Year ended August 31, 1936. Pp. 36. (Trinidad and London: Imperial College of Tropical

Rapports sur la photoluminescence présentés à la Réunion Internationale de Photoluminescence, Varsovie, 20-25 Mai 1936. Publiés par la Société Polonaise de Physique sous la rédaction de Prof. Dr. p. Pieńkowski et Dr. W. Kapusciński. (Vol. 5 des Acta Physica S. Pienkowski et Dr. W. Kapuscinski. Pol. 5 des Acta Physica
Polonica). Pp. ix + 431. (Wilno: Acta Physica Polonica.) [256 Report of the Committee on the Measurement of Geologic Time: presented at the Annual Meeting of the Division of Geology and Geography, National Research Council, May 1, 1937. Pp. ii +77. (Washington, D.C.: National Research Council.) Ringkøbing Fjords Naturhistorie i Brakvands-perioden 1915-1931. Udgivet af A. C. Johansen och $\mathbf{H}$. Blegvad, under redaktion af $\mathrm{R}$ : Spärck. (Udgivet paa Carlsbergfondets Bekostning.) Pp. vi +252 . National Geological Survey of China. Palæontologia Sinica, Series C National Geological Survey of China. Palæontologia Sinica, Series C, Vol. 7, Fascicle 5: On the Mammalian Remains from Locality at Choukoutien. By W. C. Pei. Pp. $120+6$ plates. (Peiping: The
[17

Report of the Aeronautical Research Institute, Tôkyô Imperial University. No. 151: Experimental Research on the Effectiveness of Allerons and Elevators. By Taitiro Ogawa and Kadu Itô. Pp.
$349-420$. (Tôkyô : Kôgyô Tosho Kabushiki Kaisha.) 1.00 yen. [17 